\title{
DIET ATEROGENIK PADA TIKUS PUTIH (Rattus novergicus strain Wistar) SEBAGAI MODEL HEWAN ATEROSKLEROSIS
}

\section{ATHEROGENIC DIET OF WHITE-RAT (Rattus novergicus strain Wistar) AS ATHEROSCLEROTIC ANIMAL MODEL}

\author{
Sri Murwani, Mulyohadi Ali, Ketut Muliartha \\ Laboratorium Sentral Biomedik, Fakuktas Kedokteran Brawijaya
}

\begin{abstract}
Atherosclerosis is still a major health problem, because $20 \%$ of death in the world is caused by atherosclerosis diseases like stroke and myocardial infarct. One of animal models that was successful in atherosclerosis research was New Zealand white rabbit. The purpose of this preliminary research was to determine the atherogenic diet of white rats (Rattus novergicus strain Wistar) as animal model of atherosclerosis especially to find fixed composition and time of the atherogenic diet taken.This research used male; 2 months age, 150-200 grams body weight of white rats Rattus novergicus strain Wistar. The rats were divided into 5 groups in equal number, 4 rats respectively. They were a negative control group without diet treatment and 4 groups as treatment groups which were given hipercholesterol diet. Atherogenic diet composed of PAR-S, wheat flour, cholesterol, cholic acid, pork oil and water. Data were obtained by measuring of blood cholesterol level and foam cell formation. The result showed, the atherogenic diet inducing foam cell formation and hypercholesterolemia of these rats were mixtures of PAR-S, wheat flour and $2 \%$ cholesterol, $0,2 \%$ cholic acid, $10 \%$ pork oil given for 8 weeks. It can be concluded, that white rats Rattus novergicus strain Wistar could be used as animal model for atherosclerotic research, by giving them the atherogenic diet for 8 weeks.
\end{abstract}

Key words: atherogenic diet, Rattus novergicus strain Wistar, blood cholesterol level, foam cells

\section{PENDAHULUAN}

Atherosklerosis merupakan penyakit yang dapat menyebabkan kematian di negara-negara yang sudah maju, dan diprediksi akan dapat menyebabkan kematian pada negara-negara yang sedang berkembang pada awal seperempat abad yang akan datang. Lebih dari separo kematian setiap tahun di Amerika disebabkan oleh aterosklrosis, dan lebih dari 500.000 orang meninggal setiap tahun karena infark miokardial (1). Aterosklerosis merupakan penyakit yang banyak mendapat perhatian akan tetapi prevalensi aterosklerosis sulit ditentukan, dikarenakan sebagian besar bersifat asimptomatis. Proses aterosklerosis dimulai sejak anak-anak, dan sejak itu perkembangan fatty streak tetap berlangsung. Pernah ditemukan lesi aterosklerotik di orta bayi, dan dikatakan lesi berkembang setelah umur 8-18 tahun, menjadi lesi bentuk lanjut pada umur 25 tahun, dan biasanya manifestasi klinik penyakit akan muncul pada umur 50-60 tahun, yang disebabkan karena terjadinya disrupsi plak (2). Disrupsi plak aterosklerotik dalam arteri koronari, baik yang disebabkan oleh erosi atau ruptur plak memegang peran dalam perkembangan artery coronary syndrome (ACS). Artery coronary syndrome secara klinis tidak terdeteksi, sampai timbulnya stenosis atau thrombosis, yang melanjut terjadinya gangguan aliran darah dan iskemia miokardial.
Secara klinis nampak sebagai angina pectoris, acute myocardial infarction dan sudden cardiac death $(3,4)$.

Aterosklerosis disebabkan terjadinya pembesaran dari muskuler arteri dan ditandai adanya disfungsi endotel, inflamasi vaskuler, terjadi akumulasi dari lipid, kolesterol, kalsium, debris seluler dalam intima pembuluh darah. Akumulasi tersebut di atas menyebabkan terbentuknya plak, remodeling vaskuler, akut dan khronik obstruksi luminal, abnormalitas aliran darah dan menurunnya suplai oksigen ke organ target (5).

Hiperkolesterolemia adalah suatu kondisi jumlah kolesterol darah melebihi batas normalnya. Hiperkolesterolemia merupakan hasil dari meningkatnya produksi dan atau meningkatnya penggunaan LDL (Low Density Lipoprotein). Hiperkolesterolemia dapat merupakan hiperkolesterol familial atau dapat disebabkan karena konsumsi kolesterol tinggi. Hiperkolesterol terutama fraksi LDL, adalah faktor terpenting terbentuknya aterosklerosis. Dipercayai oleh para ahli gizi, bahwa diet tinggi lemak dapat meningkatkan level kolesterol darah. Beberapa peneliti menerapkan prinsip tersebut untuk mendapatkan hewan coba yang hiperkolesterolemia $(6,7)$.

Penelitian tentang aterosklerosis menggunakan model hewan belum banyak dikembangkan. Penelitian tentang hewan coba untuk aterosklerosis pernah dilakukan oleh Ameli et al. (1997), menggunakan New Zealand white 
rabbit untuk hewan model aterosklerosis dan pengembangan vaksin LDL yang dioksidasi (1). Srivastava et al. (2000), untuk menginduksi aterosklerosis digunakan mencit (8).

Berdasarkan kepustakaan di atas, penelitian ini mencari alternatif hewan coba lainnya untuk aterosklerosis yang mudah didapat dan mudah penanganannya. Hewan coba yang digunakan adalah tikus putih (Rattus novergicus strain Wistar). Selain itu penelitian ini juga membuat pakan hiperkolesterol dan menentukan tepat lama pemberian ransum sehingga terbentuk kondisi hiperkolesterolemia dan sel busa pada aorta tikus.

Tujuan penelitian ini adalah untuk mencari komposisi diet aterogenik pada tikus putih (Rattus novergicus strain Wistar) sebagai model hewan aterosklerosis, dengan cara menentukan komposisi pakan dan lama pemberian pakan yang dapat menginduksi kondisi hiperkolesterolemia dan terbentuknya sel busa sebagai proses awal terjadinya aterosklerosis. Harap lebih lanjut, tikus putih dapat bermanfaat sebagai hewan model pada penelitianpenelitian tentang aterosklerosis.

\section{METODE}

Penelitian ini menggunakan true experimental post test control study. Sampel penelitian adalah 20 tikus putih (Rattus novergicus strain Wistar) jantan, sehat, dengan berat badan 150-200 gr, umur 2 bulan, dan dibagi menjadi 5 kelompok sama banyak, yaitu 1 Kelompok Kontrol Negatif dan 4 Kelompok Perlakuan.

\section{Kelompok Kontrol Negatif}

Kelompok yang tidak memperoleh perlakuan dan diberi pakan normal (tanpa ditambah kolesterol, asam kolat dan minyak babi).

\section{Kelompok Perlakuan (Pakan I, Pakan II, Pakan III dan Pakan IV)}

Kelompok yang mendapat diet hiperkolesterol selama 8 minggu. Pada pakannya ditambahkan kolesterol, asam kolat dan minyak babi. Pakan yang diberikan sebanyak $40 \mathrm{mg} / \mathrm{hari} / \mathrm{tikus}$. Komposisi pakan dapat dilihat pada Tabel 1.
Tabel 1. Komposisi Pakan

\begin{tabular}{lccccc}
\hline \multirow{2}{*}{ Bahan Pakan } & \multicolumn{5}{c}{ Pakan } \\
\cline { 2 - 6 } & Normal & I & II & III & IV \\
\hline Confeed PAR-S & $225 \mathrm{gr}$ & $200 \mathrm{gr}$ & $200 \mathrm{gr}$ & $200 \mathrm{gr}$ & $200 \mathrm{gr}$ \\
\hline Terigu & $100 \mathrm{gr}$ & $100 \mathrm{gr}$ & $100 \mathrm{gr}$ & $100 \mathrm{gr}$ & $100 \mathrm{gr}$ \\
\hline Kolesterol & - & $4 \mathrm{gr}$ & $8 \mathrm{gr}$ & $8 \mathrm{gr}$ & $8 \mathrm{gr}$ \\
\hline Asam kolat & - & $0,4 \mathrm{gr}$ & $0,4 \mathrm{gr}$ & $0,8 \mathrm{gr}$ & $0,8 \mathrm{gr}$ \\
\hline Minyak babi & - & $10 \mathrm{ml}$ & $10 \mathrm{ml}$ & $10 \mathrm{ml}$ & $40 \mathrm{ml}$ \\
\hline Air & $100 \mathrm{ml}$ & $85,6 \mathrm{ml}$ & $81,6 \mathrm{ml}$ & $81,2 \mathrm{ml}$ & $51,2 \mathrm{ml}$ \\
\hline
\end{tabular}

\section{Pemeriksaan kadar kolesterol darah}

Kadar kolesterol darah dilakukan pada minggu ke-8 setelah pemberian diet. Reagen pemeriksaan yang digunakan adalah "DiaSys-Cholesterol FS", secara spektrofotometrik.

\section{Pemeriksaan histopatologi terbentuknya sel busa.}

Pada minggu ke-8 tikus dibunuh, diambil arcus aortanya untuk pemeriksaan histopatologi terbentuknya sel busa.

Jaringan diwarnai menggunakan Oil Red-O (OR-O) dan Hematoxylen Eosin (HE).

\section{Analisa Data}

Data dianalisa secara statistik, menggunakan anova satu arah, dengan $\alpha=0,05$.

HASIL

Analisa secara statistik, pada hasil pengukuran kadar kolesterol darah menunjukkan hasil tidak ada perbedaan yang bermakna antara kadar kolesterol Kelompok Kontrol Negatif dengan Kelompok Perlakuan yang diberi diet aterogenik Pakan I $(p>0,05)$. Diperoleh perbedaan yang bermakna antara Kelompok Kontrol Negatif dengan Kelompok Perlakuan Pakan II, Pakan III dan Pakan IV $(p<0,05)$.

Pemeriksaan arcus aorta secara histopatologis, pada Kelompok Kontrol Negatif, Kelompok Perlakuan Pakan I dan Kelompok Perlakuan Pakan II sampai minggu ke-8 belum terbentuk sel busa (Gambar 1).

Pada penggunaan komposisi pakan II, walaupun telah berhasil meningkatkan kadar kolesterol darah secara signifikan, tetapi belum mampu menginduksi terbentuknya sel busa.

Tabel 2. Hasil Pengukuran Kadar Kolesterol Darah (mg/dl)

\begin{tabular}{cccccc}
\hline \multirow{2}{*}{ No. } & \multirow{2}{*}{ Diet Normal } & \multicolumn{4}{c}{ Diet Aterogenik } \\
\cline { 3 - 6 } & & Pakan I & Pakan II & Pakan III & Pakan IV \\
\hline 1. & 70,61 & 119,00 & 212,58 & 263,23 & 256,34 \\
\hline 2. & 58.88 & 159,30 & 182,74 & 258,33 & 376,64 \\
\hline 3. & 64,27 & 259,90 & 292,23 & 383,33 & 368,00 \\
\hline 4. & 48,71 & 208,90 & 272,99 & 311,69 & 402,00 \\
\hline Rata-rata (SD) & $60,62(9,27)$ & $186,78(61,06)$ & $240,14(51,14)$ & $304,15(58,02)$ & $351,25(68,84)$ \\
\hline
\end{tabular}


Pemeriksaan arcus aorta secara histopatologis, pada kelompok yang diberi perlakuan Pakan III dan Pakan IV sampai minggu ke-8 ditemukan adanya sel busa (Gambar 2).

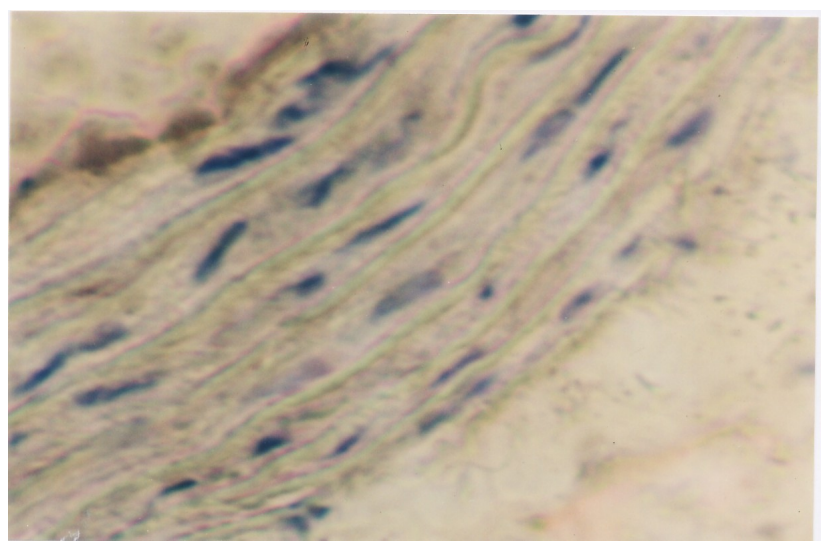

Gambar 1. Aorta normal tikus (Rattus novergicus strain Wistar) Perbesaran 10x40

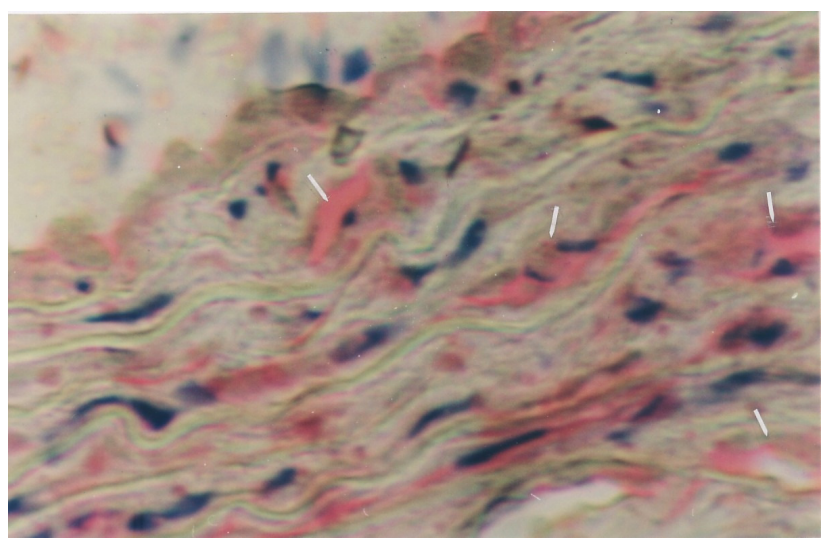

Gambar 2.Sel busa pada pewarnaan menggunakan OilRed 0 Pada sel busa: sel lebih besar, inti terdesak ke tepi, sel tercat merah (panah) Perbesaran $10 \times 40$

\section{DISKUSI}

Patomekanisme molekuler tahap inisiasi terjadinya aterosklerosis masih menjadi perdebatan. Saat ini ada tiga hipotesis yang telah diajukan untuk menjelaskan proses inisiasi aterosklerosis. Pertama, hipotesis responses to injury, menekankan peran lipoprotein yang mengandung Apo-B dan terjadinya disfungsi endotel sebagai tahap awal aterogenesis. Kedua, hipotesis LDL yang teroksidasi (oxidized LDL/Ox-LDL), menekankan pentingnya oksidasi LDL pada proses aterogenesis, seperti induksi rekruitmen makrofag dan sel-sel inflamatori lain ke ruang subendotelial. Ketiga, hipotesis respons to retention, menyebutkan bahwa tahap awal aterosklerosis adalah terjadinya retensi lipoprotein yang mengandung Apo-B di subendotelial (10).
Hipotesis LDL menekankan peran oksidasi lipoprotein pada inisiasi dan progresi aterosklerosis. Proses oksidasi LDL terjadi in vivo. Ox-LDL bersama-sama dengan lipid-lipid lainnya yang teroksidasi, juga produk degradasinya berkontribusi terhadap patofisiologi aterosklerosis melalui mekanisme yang multiple, meliputi sifat proinflamatori, sifat imunogenik dan sifat toksisitasnya. Dikatakan Ox-LDL bersifat sangat aterogenik. $(10,11)$.

Ox-LDL dapat dikenali oleh Sc-R (scavenger receptor) makrofag, kemudian diendositosis oleh makrofag dan terakumulasi sehingga terbentuk sel busa. Ox-LDL bersifat sitotoksik terhadap dinding sel arteri dan hal ini dapat menginduksi terjadinya proses inflamasi dan trombosis. Semua mayor sel pada dinding sel arteri termasuk sel endotel, smooth muscle cells dan monosit (makrofag) dapat mengoksidasi LDL. Ox-LDL menstimuli endothelium untuk mensekresi monocyte chemotatic protein 1 (MCP-1) yang merupakan faktor kemotaktik monosit dan menempatkan makrofag pada suatu tempat dan berakumulasi. Makrofag melekat pada endothelium melalui specific endothelial adhesion molecules. Makrofag kemudian bermigrasi dari sel endothelial menuju ke subendotelial. Hal tersebut merupakan tanda yang sangat penting untuk proses awal aterosklerosis (11).

Penelitian sebelumnya yang membuat diet aterogenik pada hewan coba New Zealand White Rabbit dilakukan oleh Ameli et al. (1997). Pada penelitian tersebut pada pakannya ditambahkan kolesterol $1 \%$, dan minyak kacang $3 \%$. Hasil penelitian menunjukkan, pada minggu ke 8 belum ada peningkatan kadar kolesterol darah yang bermakna, tetapi telah terbentuk fatty-streak kecil pada aorta. Pada minggu ke-16 baru terjadi peningkatan kadar kolesterol yang bermakna (1). Berdasar penelitian Ameli tersebut, pada penelitian ini diet aterogenik diberikan selama 8 minggu.

Pada penelitian ini digunakan gandum dan PARS, komponen tersebut merupakan bahan dasar untuk membuat pellet. Pemakaian kolesterol, minyak babi dan asam kolat bertujuan untuk menginduksi peningkatan LDL darah. Minyak babi mempunyai kandungan kolestrol yang lebih tinggi dibandingkan dengan minyak hewani lainnya dan minyak nabati.

Asam kolat diberikan, karena tanpa penambahan asam kolat pemberian diet aterogenik selama 8 minggu tidak dapat meningkatkan kadar kolesterol dan terbentuknya sel busa yang bermakna. Srivastava et al. (9), mengungkapkan bahwa untuk menginduksi aterosklerosis pada mencit (high-fat/high-cholesterol) diperlukan diet yang ditambah dengan asam kolat (cholic acid). Dengan diet tersebut dapat merubah gambaran lipoprotein menjadi lebih aterogenik, yaitu menurunkan kadar $\mathrm{HDL}$ dan meningkatkan LDL plasma. Diet aterogenik tanpa penambahan asam kolat 
akan meningkatkan baik HDL maupun LDL, sehingga asam kolat diduga berfungsi menurunkan kadar $\mathrm{HDL}$

\section{KESIMPULAN}

Dari hasil eksplorasi tersebut dapat ditarik kesimpulan, bahwa :

1. Komposisi pakan aterogenik untuk tikus putih (Rattus novergicus strain Wistar) adalah pakan yang ditambah kolesterol $2 \%$, asam kolat $0,2 \%$, minyak babi $5 \%$.
2. Pemberian komposisi pakan aterogenik selama 8 minggu dapat meningkatkan kadar kolesterol darah dan menginduksi terbentuknya sel busa secara bermakna

3. Tikus putih (Rattus novergicus strain Wistar) dapat dipakai sebagai hewan model untuk penelitianpenelitian aterosklerosis.

\section{DAFTAR KEPUSTAKAAN}

1. Ameli S, Hultgradh-Nilson A, Nilson J. Effect of Immunization with Homologous LDL and Oxidized LDL on Early Atherosclerosis in Hipercholesterolemic Rabbits. Atherosclerosis, Thrombosis, and Vascular Biology,1997; 16(8): 10741079

2. Orford, JL and Selwyn AP. Atherosclerosis. Instant Access to the Mind of Medicine, Medicine. Department of Internal Medicine, Brigham an Women's Hospital, Harvard Medical School, 2005

3. Worthley SG, Osende JI, Helft G, Badimon, JJ, Fuster, V. Coronary Artery Disease: Pathogenesis and Acute Coronary Syndrome. The Mount Sinai Journal of Medicine, 2001; 68: 3

4. Boyle JJ. Macrophage Activation in Atherosclerosis: Pathogenesis and Pharmacology of Plaque Rupture. Curr Vasc Pharmacol, 2005; 3 (1): 63-68

5. Orford JL. Atherosclerosis. Clinical and Research Fellow in Cardiovascular Disease, Departement of Internal Medicine, Brigham and Women's Hospital, Harvard Medical School, 2005

6. Sherer $Y$ and Schoenfeld Y. Report on the European Atherosclerosis Society Workshop on the Immune System in Atherosclerosis. http://www.rheuma21st.com/archives/schoenfeld_immune_sys_atherosclerosis\%20.html, 2001

7. Murray RK, Granner DK, Mayes PA, Rodwell VW. Harper's Biochemitry $23^{\text {rd }}$ edition. USA: Prentice Hall International Inc., 1997

8. Chan P and Tomlison B. Treating Hypercholesterolemia. Medical Progress 1997; 24(4)

9. Srivastava RAK, Srivastava N, Averna M. Dietary Cholic Acid Lower Plasma Levels of Mouse and Human Apolipoprotein A-I Primarily Via Transcriptional Mechanism. Eur.J.Biochem 2000; 267: 4272-4280

10. Hansson GK. Cell-Mediated Immunity in Atherosclerosis. Journal of Cardiovascular Risk 1997; 4(5/6): 301-311

11. Aviram M and Fuhrman B. LDL Oxidation by Arterial Wall Macrophag Depends on The Oxidative Status in The lipoprotein and The Cells : Role of Prooxidation vs Antioxidant. Mol Cell Biochem 1998; 188(1-2):149-159 

